purchase facilities in some areas, but all of these can be surr junted. Mr. Burnell suggests that all undertakings should be prepared to take over agreements on the original terms.

\section{Cancer Research and Treatment in Australasia}

THE Tenth Australian - New Zealand Cancer Conference, held at Wellington in February of last year, was concerned with cancer control, reports on particular forms of treatment (Koch and Baker) and radiological physics. The part being played by the physicist in the use of $\mathrm{X}$-rays and radium is a rapidly growing one; this arises from the growth of quantitative methods in giving doses of radiation to patients. These methods not only allow the specification of the dose actually given, but also they aim at arranging for the optimum distribution of the radiation throughout the tissues. The report from the Commonwealth X-ray and Radium Laboratory shows a wide range of activity at this centre, with a most progressive outlook as to the function of the physicist in collaboration. It is good to learn that the Commonwealth Department of Health has made the services of the physicists-in-charge available to radiotherapeutic institutions for consultation on the various physical problems of X-ray and radium therapy, and advantage is being taken of such facilities, doubtless to the benefit of patients.

\section{American Zeal for Education}

School and college summaries seem perpetual in the United States. "A Review of Educational Legislation : 1937 and 1938", by Mr. Ward Keesecker (Washington, D.C., 10 cents), has involved, we are told, a study of 1,500 enactments. The main tendencies exhibited are increased support from the State with more control and the establishment of minimum State-aid foundations. Pennsylvania in 1937 paid special attention to local schools, county boards of directors, the merging of schools poorly attended, and transportation routes. In Georgia all teachers now have to be classified according to their training and experience. In Nevada, amendment of the liquor-licence law increased the amount set aside for education. Tennessee added $4 \frac{1}{2}$ million dollars to school funds. Two States, Arkansas and Vermont, made teaching on the effects of alcohol compulsory from grades 3 to 8 . Montana required all public schools to give instruction in music, art, and elementary agriculture. Several States increased the minimum salaries of teachers and their benefits on retirement, and Kentucky forbade city schools to discriminate against married women as teachers. It is clear that throughout the country great pains have been taken to see that education is better managed and financed.

\section{Smithsonian Institution: Annual Report}

THE report of the secretary of the Smithsonian Institution for the year ended June 30, 1939, which has been published, refers to the completion by the Astrophysical Observatory of the enormous task of recomputing the daily solar constant values from all its observing stations since 1923, apart from the final corrections and general discussion, which were expected to be concluded by October 1939. The Division of Radiation and Organisms gave much attention during the year to photosynthesis, factors influencing plant growth and the stimulative action of ultra-violet radiation. Experimental evidence was obtained indicating the formation during photosynthesis of a material which combines with or absorbs carbon dioxide and resembles chlorophyll in character. A quantitative method for the isolation of hormones from plants is being developed, and the effect of radiation on the growth of excised roots and leaves has been investigated.

Numerous scientific field investigations in anthropology have been conducted by the National Museum as well as archæological and ethnological expeditions by the Bureau of American Ethnology, including investigations of Folsom man at the Lindenmeier site in northern Colorado, studies in the northern province of the Navaho Indians, as well as in western South America. In addition to the report of the Executive Committee of the Board of Regents, appendixes include detailed reports of the work of the various divisions, including the National Gallery of Art, the Freer Gallery of Art, the National Collection of Fine Arts and the National Zoological Park, the last-named giving a detailed list of animals in the collection that had not previously been exhibited.

\section{Awards of the Finney-Howell Research Foundation}

The Finney-Howell Research Foundation, Inc., of Baltimore, Maryland, announces that fellowships for research into the cause or causes and the treatment of cancer were renewed for the following: P. C. Aebersold, working at the Radiation Laboratory of the University of California at Berkeley; G. M. Badger, working at the Royal Cancer Hospital (Free) at London, England; L1. W. Law, working at the Roscoe B. Jackson Memorial Laboratory at Bar Harbor, Maine; J. L. Melnick, working at Yale University School of Medicine at New Haven, Conn.; J. F. Menke, working at Stanford University Hospital, at San Francisco, California; J. L. Wood, working in the Division of Chemistry, Harvard University, at Cambridge, Mass.; P. C. Zamecnik, working at Copenhagen. New fellowships have been awarded as follows: J. C. Abels, to work at the Memorial Hospital for Cancer at New York City; M. A. Graubard, to work at Clark University, Worcester, Mass. ; J. W. Howard, to work at Thorndike Memorial Laboratory, Boston City Hospital, Boston, Mass.; B. E. Kline, to work at the Department of Physiology, University of Wisconsin, Madison; Margaret $\mathrm{N}$. Lewis, to work at Crocker Radiation Laboratory, University of California, Berkeley; A. Marshak, to work at the Radiation Laboratory, University of California, Berkeley; Dr. G. C. Gey was also awarded a grant of 2,000 dollars to carry on his work on cancer at the Johns Hopkins Medical School. The closing date for applications for awards during 1941 is January $1,1941$. 